\title{
Narrativa e Internet: \\ Possibilidades e Limites do Atendimento Psicoterápico Mediado pelo Computador
}

\author{
Narrative and internet: \\ possibilities and restrictions of Psychological assistance by computers
}

Resumo: Este artigo tem como objetivo refletir sobre a possibilidade do atendimento psicológico mediado pelo computador. Buscamos relacionar a psicoterapia com as descrições das tecnologias da inteligência - a oralidade, a escrita e a informática. Concluímos que a clínica, enquanto entidade instituída, envolve a necessidade da presença física do terapeuta, o que não inviabiliza o esforço de pensarmos outras formas de encontros.

Palavras-Chaves: Narrativa, psicoterapia, computador.

Abstarct: This paper aims to reflect about the possibility of psychological attendance by computer. We tried to make a connection between psychoterapy and the description of the technologies of intelligence - orality, writing and data processing. We concluded that clinical attendance, as an instituted entity, involves the necessity of the physical presence of the therapist, what doesn't put aside the effort of finding other modalities of meetings.

Key Words: Narrative, psychoterapy, computer.

\section{Pinto de Almeida}

Psicólogo, Mestre em Psicologia pela UFF. Doutorando em Psicologia na PUC/RJ.

\section{Joelson \\ Tavares Rodrigues}

Médico psiquiatra. Mestre em Psicologia pela UFF. Doutorando em Psicologia na UFRJ.

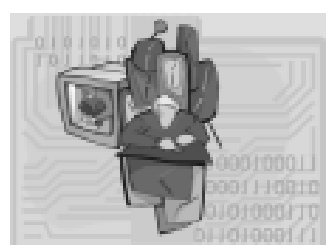

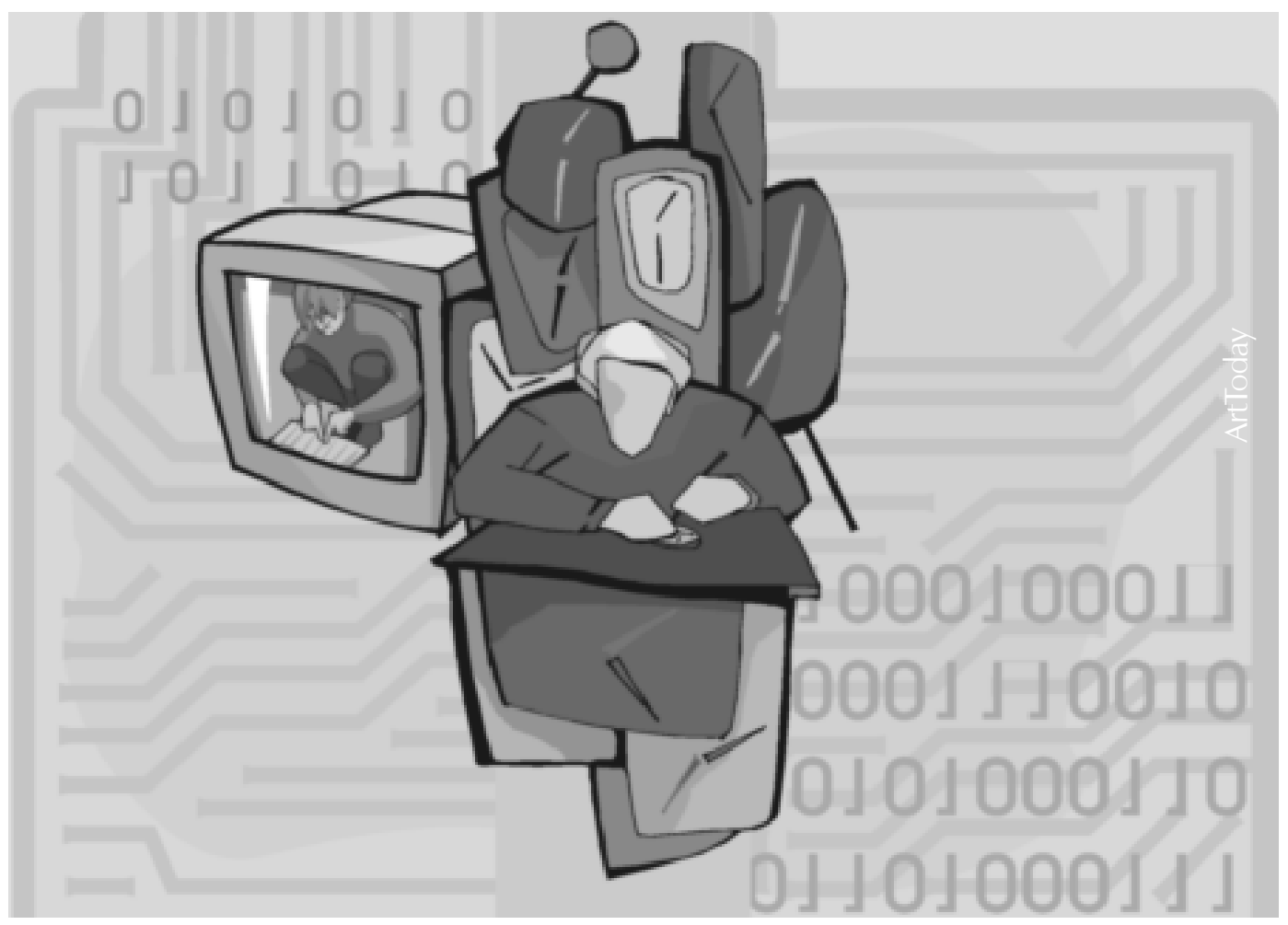

O presente trabalho tem como objetivo traçar algumas reflexões acerca de uma polêmica que envolve a existência do chamado ciberespaço e sua relação com a Psicologia, mais especificamente, com a psicoterapia. Sob o pano de fundo de uma análise hermenêutica da questão, tencionamos discutir a possibilidade ou não do atendimento psicológico mediado pelo computador.
Para alcançarmos o requerido, nós nos utilizaremos do pensamento de Pierre Lévy, que tem por objeto de estudo o espaço cibernético ou ciberespaço e suas relações com a subjetividade.

Pensar a internet nos dias em que vivemos se tornou um verdadeiro "must". Os reflexos das mudanças por ela instauradas transcendem, em muito, o território da informática. Em uma época em que o 
saber técnico assume proporções inimagináveis , a tecnologia atravessa a vida condicionando os comportamentos humanos. No campo da Psicologia, surgem questionamentos até então inexistentes, dentre os quais se destaca o da possibilidade de um atendimento psicológico via Internet. A resposta a essa pergunta não pode ser dada, entretanto, sem dificuldades, exigindo de nossa parte considerações adicionais. A primeira delas é a necessidade de pensarmos a especificidade do espaço que comumente chamamos de ciberespaço, o que fatalmente nos leva a refletir sobre o próprio momento histórico em que tal espaço se constrói.

Zymunt Bauman (1998), em seu livro O Mal-Estar da pós-Modernidade, pensando o contemporâneo, refaz a assertiva de Freud em O Mal-Estar da Civilização, segundo a qual o processo civilizatório se dá a partir de uma renúncia do instinto, com uma conseqüente restrição da liberdade - ganhase em segurança, na mesma medida em que se perde em liberdade. Para Bauman, é esse movimento que marca a modernidade, já que, segundo o seu entendimento, modernidade e civilização se eqüivalem. Enquanto a modernidade poderia ser caracterizada por uma busca de ideais de beleza, limpeza e ordem, o contemporâneo conceituado por Bauman como pósmodernidade - é marcado pela fragmentação, a desregulamentação e a mudança. Esses movimentos, caracteristicamente transformadores, inaugurariam uma era na qual as certezas são substituídas pelos pontos de interrogação; os portos seguros já não existem mais, condenando-nos à condição de barcos à deriva, necessitados de encontrar, por si mesmos, seu próprio rumo perderíamos, assim, em segurança, ganhando, ao mesmo tempo, em liberdade, uma liberdade individual, que nos afastaria da monotonia, mas nos traria como companheiras a angústia e a insônia. Nós nos depararíamos, então, com os sofrimentos gerados pela "perda de ancoragem", pelo fato de termos que nos confrontar com a incerteza, sempre presente, fruto das mudanças econômicas, sociais e políticas ocorridas no mundo, que nos legaram uma estrutura que carece de lógica, uma prioridade absoluta dos valores do "mercado", uma mídia que propala, a todo o tempo, a volatilidade de todas as verdades e, finalmente, uma fragmentação da dimensão coletiva, do valor da polis, da segurança, anteriormente outorgada pela família, os amigos e a sociedade em geral.

O espaço cibernético, ou a cibercultura ${ }^{2}$, é um dos retratos da contemporaneidade. A liberdade se faz presente quase sem restrições: liberdade de movimento, liberdade de idéias, de sonhos e até mesmo a liberdade de se assumir a identidade que se deseja. Um espaço sem regras claras, desregulamentado, muito distante dos ideais modernos. Na Internet, há uma espécie de desmaterialização, ou melhor, de uma quase fluidez de seu usuário. É o turista de Zigmunt Bauman que tem horror ao repouso. Em O MalEstar da pós-Modernidade, Bauman (1998) fala de duas figuras que habitam a pós-modernidade ${ }^{3}$ : os turistas e os vagabundos, ambos surgidos nessa época atravessada por uma sociedade de consumo, onde a velocidade desenfreada move os desejos e anseios dos homens, sendo a liberdade de escolha o mais precioso dos bens. Em nossa época, a velocidade condiciona comportamentos e expectativas, que se afastam da fixidez característica da modernidade.

"Manter o jogo curto significa tomar cuidado com os compromissos a longo prazo. Recusar-se a 'se fixar' de uma maneira ou outra. Não se prender a um lugar, por mais agradável que a escala presente possa parecer. (...) Não jurar coerência e lealdade a nada ou a ninguém" (BAUMAN, 1998, p. 113). Turistas e vagabundos são os habitantes do contemporâneo. Segundo a perspectiva de Bauman, eles retratam os heróis e as vítimas de nosso tempo. O turistas são aqueles que se locomovem, mas tiveram o direito de assim escolher. Já os vagabundos são obrigados a perambular pelas ruas anônimas das inúmeras cidades espalhadas pelo mundo. São os indesejados, o refugo, o produto da exclusão.

"Os turistas se demoram ou se movem segundo o desejo de seus corações. (...) Os vagabundos, porém, sabem que não ficarão por muito tempo, por mais intensamente que o desejem, uma vez que em nenhum lugar em que parem são bemvindos.(...) Os turistas viajam porque querem; os vagabundos, porque não têm nenhuma outra escolha" (Bauman, 1998, p. 118).

Os internautas ou usuários das conexões estabelecidas na Internet são turistas que viajam pelos mares de informação virtual. Consomem o novo, o que estranha os sentidos, não se fixando por muito tempo em um site e, sim, perambulando, movendo-se de link em link, desejando navegar, adquirir informações, sejam elas úteis ou não, pouco importa.

Esse anseio de velocidade, a constante pressão do tempo, a busca de se vencer os limites espaciais, a necessidade de se produzir mais e melhor, afeta de uma forma ou de outra as disciplinas teóricas e, mais do que elas, as práticas profissionais. Os psicossociólogos, como Nicole Aubert e Vicent de Gaulejac (1993), se referem a uma cultura da urgência e da excelência, que marca os trabalhadores contemporâneos, moldando-os
1 A utilização do termo contemporaneidade é uma maneira sutil de nos ausentarmos da Querela entre Modernos e Pós-modernos. Neste trabalho, intentamos refleti acerca do ciberespaço, considerado aqui como um dos retratos do contemporâneo.

2 Ciberculturaé um neologismo utilizado por Lévy (1999) para designar "(...) o conjunto de técnicas (materiais e intelectuais), de práticas, de atitudes, de modos de pensamento e de valores que se desenvolvem juntamente com o crescimento do ciberespaço" (p. 17).

3 A pós-modernidade seria outro retrato da contemporaneidade, cujas características e semelhanças com o ciberespaço nos absteremos em apresentar; pois, comojá explicado, não queremos entrar no embate entre modernos e pós-modernos. 
subjetivamente. É dentro desse horizonte que essa nova tecnologia midiática, a Internet, começa a parecer tentadora para o campo da Psicologia, colocando uma questão de extrema importância para os psicoterapeutas: É possível o tratamento psicológico via Internet? Se for possível, como fazêlo?

Atentos a esse problema, os conselhos de psicologia do Brasil promoveram debates fervorosos acerca do tema em questão. Após longas discussões, o Conselho Federal de Psicologia publicou, em Setembro de 2000, a Resolução CFP № 003/2000, que regulamenta o atendimento psicoterapêutico mediado por computador. Essa resolução possui nove artigos.

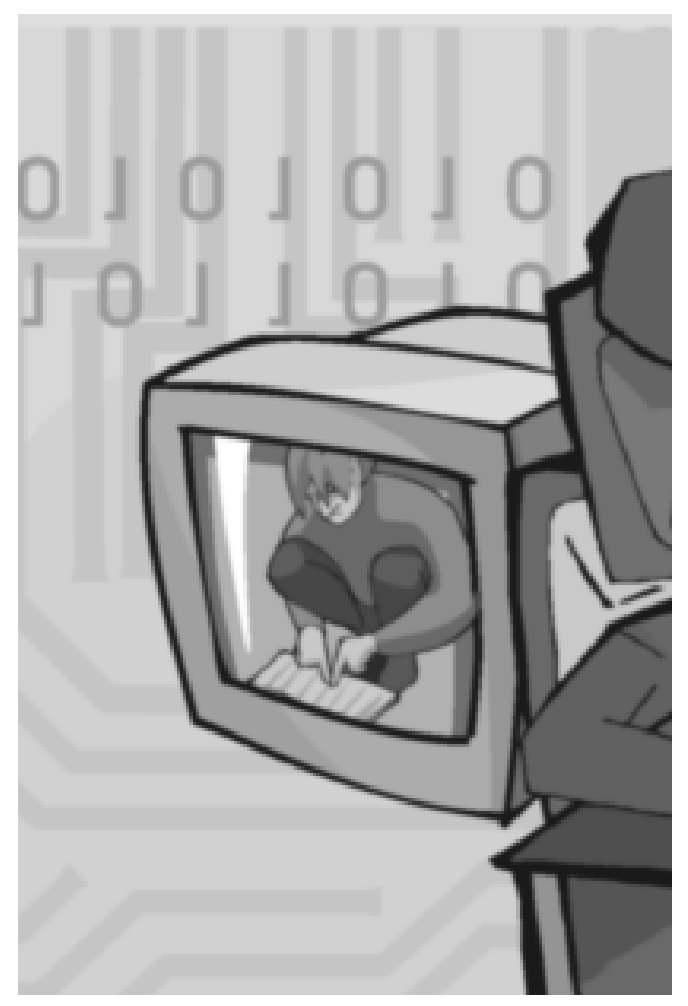

O documento afirma que essa modalidade de atendimento psicoterápico só pode ser efetuada como pesquisa (art. 1ํ). A natureza desse projeto caracteriza-se pela não remuneração de nenhuma das partes envolvidas, pelo consentimento do usuário e conhecimento da experimentalidade do atendimento, pela possibilidade de desistência do pesquisado a qualquer momento, pelo sigilo ligado à identidade do participante da pesquisa, pela importância da segurança e da criptografia e da obrigação de aviso de qualquer violação ocorrida no sistema (art. 1ํ). A validação desse experimento será feita mediante "divulgação dos resultados e informação dada ao público relacionada ao tema terá de caracterizá-lo como experimental.

Os serviços não psicoterapêuticos, por outro lado, foram regulamentados para serem efetuados através do computador. Os interessados em exercê-lo, entretanto, têm que obrigatoriamente se cadastrar via meio eletrônico (art. 5으).

O art. 6 0 aponta para a necessidade de os profissionais envolvidos nos dois tipos de serviços se submeterem a identificação e cadastramento mediante certificação eletrônica. Já no art. 7oㅡ, afirma-se que esses tipos de trabalhos deverão ser acompanhados e fiscalizados pela Comissão Nacional durante cinco anos.

A resolução do Conselho, em síntese, conclui pela validação do atendimento psicológico mediado pelo computador apenas para pesquisa, sinalizando para o fato de que serão necessários estudos adicionais, com o propósito de se concluir definitivamente pela propriedade ou não dessa modalidade de atendimento.

Do ponto de vista epistemológico, por outro lado, para que possamos chegar a uma conclusão, uma outra questão se coloca, a do fundamento da psicoterapia. Como podemos pensar a validação de um atendimento psicoterápico mediado pelo computador, se não nos perguntamos o que realmente seria uma psicoterapia? Quais são as suas bases? O que essencialmente a caracteriza? E outro problema que complementa essa questão: quais são as especificações do ciberespaço? E, finalmente, quais seriam as possíveis relações entre psicoterapia e o espaço cibernético?

Tentando chegar às respostas a esses questionamentos, ocorre-nos uma outra questão: como pensar uma psicoterapia, trabalho que requer uma demarcação território-referencial, em um espaço regido pela fluidez? Como estabelecer uma nova modalidade de terapia em um espaço que não comporta as mesmas características espaciais e materiais de setting comum? Seria de fato essa uma impossibilidade absoluta?

Para tecer essa reflexão, tomemos certos aspectos do pensamento de Pierre Lévy, que tem como objeto de estudo a produção de subjetividade encontrada no espaço cibernético. Utilizemo-nos, para subsidiar nossa análise, de As Três Tecnologias da Inteligência, de Lévy (1993). Nessa obra, o autor diferencia a oralidade, a escrita e a informática, cada uma delas influenciando os comportamentos humanos em diferentes tempos históricos. Elas também podem ser pensadas ocorrendo concomitantemente. Em Cibercultura (1999), ele explica que as sociedades são condicionadas pelas 
técnicas que as constituem, e isso não quer dizer que elas sejam determinadas por estas, mas, sim, que a técnica "abre algumas possibilidades, que algumas opções culturais ou sociais não poderiam ser pensadas a sério sem sua presença" (Lévy, 1999, p. 25).

Para Lévy (1993), a função da oralidade em tempos onde a escrita não teve ainda sua gênese seria a de gerir uma memória social calcada em narrativas e mitos. Segundo ele, os mitos seriam caracterizados por representações fortemente interligadas por relações de causa e efeito, levando em conta seu caráter concreto e familiar pautado nos problemas da vida, ou seja, eles se caracterizariam por histórias construídas sobre o pano de fundo de problemas que envolvem a vida de uma determinada tribo, cuja enunciação se calca na causalidade para, assim, dar respostas a questões concretas e familiares que fazem parte da vivência dos membros da tribo.

Para pensarmos a narrativa, reportemo-nos a Walter Benjamim. Em seu texto intitulado $O$ Narrador, Benjamim (1988) destaca alguns elementos que, na narrativa, caracterizariam a relação entre narrador e ouvinte. $\mathrm{O}$ primeiro aspecto apontado por Benjamim que gostaríamos de ressaltar é a implicação do narrador com o narrado, já que ele se encontra "embolado" com sua própria mensagem. Não há, portanto, neutralidade quando se narra, pois os sentidos que surgem no processo da narrativa se darão sempre a partir de um território referencial, uma história, que é a do narrador. $O$ segundo aspecto seria a necessidade da companhia entre ouvinte e narrador, pois nenhum dos dois se encontra sozinho nesse jogo, o que significa dizer que os sentidos desvelados não são propriedade do narrador, nem, por outro lado, a apreensão perfeita do narrado por aquele que ouve. Ao invés disto, eles se dão a partir do encontro entre narrador e ouvinte, no qual os dois estão igualmente envolvidos. A narrativa possibilita a elaboração de uma mensagem provida de um "colorido" todo próprio à relação que se estabelece entre narrador e receptor. Ela tem "colorido", tem vida, pois o seu sentido é constituído no mesmo tempo, tanto pelo narrador quanto pelo receptor, no momento mesmo em que ela se dá.

Calcando-se nas práticas do mito e da narrativa, a oralidade constrói uma temporalidade circular e um devir sem referenciais nem vestígios. Uma temporalidade circular é regida pelo próprio processo da memória do povo, a narrativa e o mito circulam em um movimento que vai da sua recepção a uma nova evocação, gerando uma nova recepção, ou seja, $A$ narra um fato a $B, B$ narra a $C$ e assim ininterruptamente, gerando a memória da tribo. Se não há escrita, não há traços deixados que possam evocar uma lembrança sem a utilização da voz como produtora de sentido. Em função desse fato é que podemos falar de um devir sem referenciais e sem vestígios. Lévy (1993) diz que "as narrativas se alteram ao sabor das circunstâncias, pois a transmissão é também uma recriação, mas ninguém sabe medir essas derivas, por falta de ponto fixo" (p. 84). Sobre o pano de fundo da imediatez - é imediato, pois não há mediação de traços que remontam a memória -, a conservação e a significação fundamentam a produção de linguagem, isto é, deve-se, através das narrativas e dos mitos, conservar e dar significado aos atos e à história do povo.

Quando a escrita toma corpo na história, ela traz um distanciamento entre os discursos produzidos e as circunstâncias geradoras de sentido. Nisso, diferencia-se do relato narrativo, pois este último leva em conta a implicação relacional entre emissor e receptor da mensagem. Obviamente tal relação também se faz presente na escrita. Afinal, na leitura existe igualmente um ato interpretativo, no qual as possibilidades de sentido que se desvelam se dão a partir da experiência, tanto de quem lê, quanto de quem escreve. Entretanto, há aí um hiato temporal que diferencia, essencialmente, a escrita da oralidade.

Em sociedades atravessadas pela escrita observase, então, uma obscuridade da mensagem, devido ao hiato temporal apresentado entre a produção do texto e a leitura. Isso faz com que surja a necessidade de uma maneira própria de ler, a interpretação fundada numa exigência de verdade, já que o texto deve passar pelo crivo da análise. Para Lévy (1993), "a escrita, ao separar a mensagem das situações onde são usados e produzidos os discursos, suscita a ambição teórica e as pretensões à universalidade" (p. 91). Essa exigência de verdade, sustentada pelas noções de universalidade, crítica e objetividade, detém uma dimensão temporal linear. Ao contrário da oralidade, essa dinâmica está ligada a vestígios e acúmulos, ou seja, o papel ou o suporte para a textualidade passa a metaforizar, de certa forma, a memória. Ao metaforizar os traços mnêmicos, a escrita produz letras, vestígios, pistas que evocam a memória de um povo. No entanto, a produção de linguagem não precisa mais, através da escrita, constituir o sentido em uma relação de intimidade entre narrador e receptor. É como a memória: nós podemos nos lembrar de nossa infância, de nossa adolescência, bastando termos um traço impresso no aparato psíquico. No caso da escrita, não precisamos estar em uma mesma época do escritor do livro que lemos para que o entendamos. Porém, como podemos ler Aristóteles, se ele escreveu há tanto tempo? Há uma necessidade que surge concomitantemente com a escrita: é a noção de
Quando a escrita

toma corpo na

história, ela traz um

distanciamento entre

os discursos

produzidos e as

circunstâncias

geradoras de sentido. 
verdade. Deve haver uma ordenação no mundo dos livros que possibilite, desse modo, a leitura correta, ou, pelo menos, que nós nos abstenhamos da leitura errada, equívoca. Essa possibilidade de direcionamento da leitura demonstra a característica acumulativa nas sociedades atravessadas pela escrita. Há os traços, os vestígios; no entanto, eles se acumulam, proporcionando uma dinâmica cronológica que visa a uma verdade, que aponta para uma melhor interpretação: essa temporalidade é meramente linear.

Já na informática, Lévy (1993) assinala que a temporalidade produzida por essa tecnologia é marcada pelas interseções das redes; por isso, seu tempo não é nem circular, nem linear, mas local e pontual, ou seja, ela não produz círculos de memorização sem estar calcada em nenhum traço, apenas na vontade de narrar e contar as histórias de um povo, como na oralidade, e produz linhas calcadas em traços acumulados que visam a um objetivo maior, que seria a verdade nua e crua, como na escrita. A terceira tecnologia da inteligência gera pontos que se caracterizam pelos links, interseções de redes, produções de sentido pontuais e meramente localizadas em um espaço determinado que não visa a uma verdade absoluta, mas somente a uma verdade local e pontual, chamada de eficácia.

Lévy (1993) ainda aponta que o tempo da informática se afigura, além de local, como um tempo de devir (pluralidade de devires imediatos), em que a velocidade (velocidades puras sem horizonte) se apresenta claramente em seu jogo. São devires imediatos devido ao fato de as conexões estabelecerem interseções de verdade, porém, elas duram apenas enquanto se estiver conectado a elas. A velocidade não as deixa fixarem-se por muito tempo. Essa velocidade sem objetivo e sem horizonte não visa a nada, apenas a saltar de link em link. Ao falar do devir informático, Lévy (1993) explica que “(...) a superfície deslizante das telas não retém nada; nela, toda explicação possível se torna nebulosa e se apaga, contenta-se em fazer deslizar palavras e imagens espetaculares, que já estarão esquecidas no dia seguinte" (p. 116).

Com o surgimento dessa nova dinâmica cronológica se evidencia, segundo Lévy (1993), o declínio das noções de verdade, universalidade, crítica e objetividade. Isso ocorre devido ao fato de os critérios dominantes de enunciação serem agora sustentados por uma exigência mais local e pontual que se caracteriza pela pertinência local, eficácia e mudanças.

Como conseqüência das exigências desses critérios, as teorias dão o seu lugar aos modelos. Tudo isso porque as teorias visavam a uma verdade cristalizada e absoluta, própria da escrita. Já os modelos são experimentais, mais locais. Um modelo pode funcionar para uma coisa e não para outra, o que vale é a sua pertinência, ou melhor, ele se baseia na exigência de uma melhor performatividade e eficácia.

Tendo em vista as reflexões que fizemos até então, torna-se necessário questionarmos por qual tecnologia da inteligência o tratamento psicológico é atravessado.

Nosso cliente vem ao consultório quando as mazelas e sofrimentos de sua vida a tornam insuportável. Nós o convidamos a relatar seu trajeto. Ele, como um guia, constrói uma história de sua viagem por uma cidade cheia de ruínas, dizendo: "Esse prédio ficou em ruínas porque o engenheiro responsável não soube fazê-lo!" Os suportes referenciais de sua existência estão em pedaços. Mas quem é o agente da destruição? Essa é a pergunta fundamental da intervenção psicológica, que necessariamente demanda a implicação desse que relata a história.

Podemos, então, pensar que o atendimento psicológico se nutre de relatos e intervenções. Estamos, tanto cliente quanto psicoterapeuta, mergulhados, envolvidos na constituição de sentido. Aqui, a filiação do atendimento psicológico e a narração se fazem evidentes. Mas o que seriam as intervenções? Elementos constitutivos dos jogos de linguagem presentes na clínica psicológica, que remetem o emissor da mensagem, no caso o cliente, à sua implicação, ou íntima relação com os componentes narrados?

Vemos, então, que o atendimento psicológico é permeado pela narração. Afinal de contas, por que não produzir um atendimento psicológico via cartas? Meu analista mora em uma cidade distante. De 15 em 15 dias, mando uma carta para ele, apresentando-lhe meu sofrimento. Isso poderia retratar uma relação terapêutica? Mas como conceber uma tal relação, se a escrita traz um hiato temporal no seio da mensagem, fazendo dela uma teia um tanto obscura de significações?

É importante ressaltarmos, no entanto, que a Internet torna complexa a nossa questão à medida em que ela possibilita uma espécie de imediatez. Embora presente uma linguagem, em sua maioria, baseada na escrita, ela não tem, necessariamente, como obstáculo, o hiato temporal, tal como descrito por Lévy. Retornamos, dessa forma, à nossa pergunta inicial: será possível construirmos, através de uma relação mediada pelo computador, uma narrativa com as especificidades da narrativa psicológica? O primeiro ponto, ou seja, a imediatez, parece resolvido pelo contato virtual. Surge, então, a necessidade de questionarmos que outros elementos seriam essenciais a esse contato. 
Se a imediatez, característica do discurso narrativo, é fundamental para o tratamento psicológico, por que não se pode atender periodicamente um determinado paciente apenas com o uso do telefone? Será que a presença física do terapeuta já é intervenção, trabalho terapêutico? Estarem, terapeuta e paciente, em um mesmo espaço se constitui em uma prerrogativa essencial ao atendimento psicoterápico?

Vez por outra, um paciente nos telefona, fala de suas aflições mais imediatas e, quando intervimos, estamos, sim, agindo terapeuticamente, pois qualquer contato entre terapeuta e paciente será, ou deverá ser, sempre permeado pelas características particulares dessa relação. Da mesma forma, poderemos ocasionalmente responder a uma mensagem de um paciente nosso que se encontre em viagem, ou mesmo "conversar" com ele por algum sistema de comunicação on line. Resta saber, entretanto, se esses contatos fortuitos poderão ocupar o papel central e substituir o encontro mesmo entre terapeuta e paciente.

Responder a essa pergunta também não carece de dificuldade, pois precisaremos questionar o que, de fato, constitui um encontro. Já afirmamos que o problema da imediatez parece estar resolvido; entretanto, poderíamos enumerar aqui diversos limites impostos pelo computador a um contato tal qual ele se dá em uma relação "real". É bem verdade que já não estamos mais restritos a uma comunicação escrita. Se hoje os recursos que permitem a troca de imagem e de som ainda são limitados, os avanços tecnológicos nos permitem supor que é apenas uma questão de tempo o seu pleno desenvolvimento e popularização. É possível ainda imaginarmos que, em um momento não tão distante assim, poderemos ser capazes de emitir imagens tridimensionais que mimetizem, de uma forma muito próxima, a presença física do outro. Mesmo nessa condição, ou mais do que isso, ainda que fossemos capazes de reproduzir o olfato, o tato ou o paladar, parece-nos que estaríamos muito distantes de um encontro real, tal qual o que ocorre entre duas pessoas que estão em um mesmo espaço físico. Tal afirmação é, na verdade, muito mas intuída do que teorizada; talvez seja mesmo difícil afirmarmos o que falta. $O$ fato é que, pensando o contato que temos como profissionais com os nossos pacientes, nós nos damos conta de que existe algo que transcende a reunião dos cinco sentidos, mas que é, ao mesmo tempo, indispensável para que possamos definir esse contato como um encontro.

Sendo assim, a questão do avanço tecnológico ou da possibilidade de um contato mais eficaz, rápido ou qualquer outro adjetivo que possamos encontrar, se revela secundária, sendo substituída pela necessidade de nos perguntarmos se esse outro modo de relação, irremissivelmente diverso da relação real, tem, em seu seio, como possibilidade, o atendimento psicoterápico.

A impressão que temos é que, tomando como paradigma a noção formal da clínica psicoterápica - a instituição clínica - com seus esquemas, horários e regras a serem seguidas, a resposta a esse questionamento será negativa. Dentro desse modelo, parece-nos ser indispensável a presença física do psicoterapeuta. No entanto, será que essa tentativa de definir a clínica esgota todas as possibilidades do que ela pode ser? Acreditamos que não. Baseados nessa idéia é que entendemos que, embora não se possa afirmar positivamente a validade do atendimento virtual, não se pode, por outro lado, colocá-lo de lado sem maiores indagações. Pode-se ver até vantagens nessa forma de intervenção, como, por exemplo, maior facilidade de revelação por parte do paciente sem maiores preocupações com o olhar ou o julgamento do analista. Ao mesmo tempo, não se pode deixar de enxergar as desvantagens, como o risco de uma idealização facilitada pelo afastamento físico.

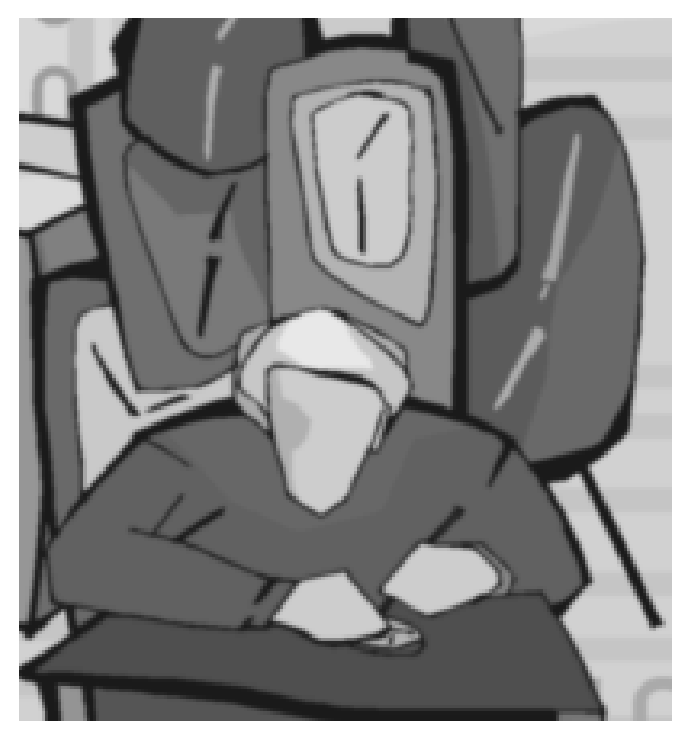

Pode-se ver até vantagens nessa forma de intervenção, como, por exemplo, maior facilidade de revelação por parte do paciente sem maiores preocupações como olhar ou 0 julgamento do analista.

De fato, não temos, ao menos por enquanto, as respostas.

É preciso, entretanto, manter vivo o questionamento, já que não nos cabe a fixação em modelos representacionais - no caso em questão, o modelo psicoterápico - sem estarmos constantemente colocando-o em xeque.

É importante considerarmos que o que entendemos por psicoterapia nada mais é do que uma tentativa de organização e sistematização do que é fundamental: o encontro entre dois seres humanos, no qual um se mostra aparelhado para ajudar o outro, sem, entretanto, negar o fato de 
que ambos continuamente se afetam. A psicoterapia não é, dessa forma, uma entidade natural; ao invés disso, constituiu-se, em um dado momento histórico, atravessada por contingências que a fizeram surgir enquanto acontecimento. $\mathrm{Na}$ verdade, ela vem sendo constantemente reinventada. Quando pensamos a psicoterapia, desta ou daquela maneira, estamos apenas formulando uma representação conceitual que atende às nossas expectativas de sistematização e segurança, mas que, ao mesmo tempo, deve ser continuamente colocada em jogo no devir temporal. Do contrário, nós nos colocaremos em uma camisa de força, acreditando que chegamos a um modelo perfeito e, por isso, imutável. Ao fazermos isso, nós nos fechamos aos movimentos disruptores, produtores de estranheza.
A velocidade com que as nossas verdades são desconstruídas nos permite refletir que, se no presente momento, uma terapia virtual parece não corresponder às expectativas que criamos para um atendimento psicoterápico, nada nos impede de pensar que no futuro venhamos a refazer tudo o que hoje afirmamos. Acima de tudo, o que nos parece necessário é nos mantermos centrados no que é fundamental nesse encontro que chamamos de psicoterapia. Esse elemento essencial transcende qualquer técnica ou modelo, não pode ser domesticado sob pena de perder aquilo que o caracteriza: para ele, não há palavras ou definições; ele apenas se dá à medida em que dois ou mais seres humanos resolvem caminhar juntos e, a partir desse "estar juntos", constroem um espaço de transformação e de mudança.

\section{Quando pensamos a psicoterapia, desta ou daquela maneira, estamos apenas formulando um representação conceitual que atende às nossas expectativas de sistematização e segurança, mas que, ao mesmo tempo, deve ser continuamente colocada em jogo no devir temporal.}

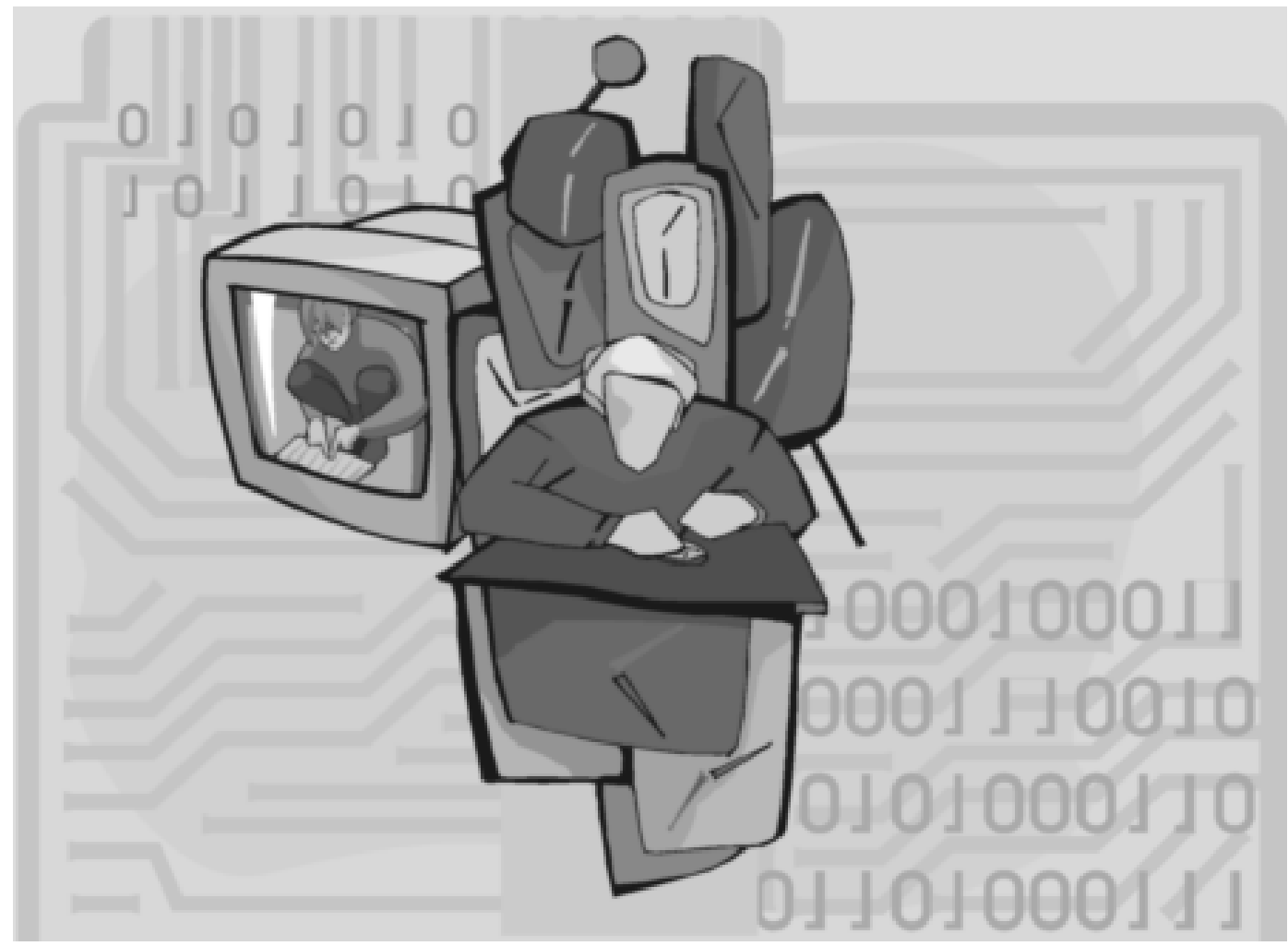


AUBERT, N \& Gaulejac, V. El Coste de la Excelencia. Buenos Aires: Paidos, 1993.

BAUMAN, Z. O Mal-Estar na pós-Modernidade. Rio de Janeiro: Zahar 1998.

BENJAMIN, W. O Narrador. In: Obras Escolhidas I, Magia e Técnica. São Paulo: Brasiliense, 1988.
LÉVY, P. As Três Tecnologias da Inteligência. Rio de Janeiro: Ed.34, 1993.

Referências Cibercultura. Rio de Janeiro: Ed.34, 1999 